\title{
THE ECONOMIC OPPORTUNITIES OF RENEWABLE ENERGY RESOURCES IN AZERBAIJAN: MAJOR CHALLENGES AND SCENARIOS
}

\author{
Ali Karimli ${ }^{1}$, Asef Aghayev ${ }^{2}$ \\ ${ }^{1}$ Faculty of Economics, Azerbaijan University of Architecture and Construction, \\ alikerimli@hotmail.com, +994514878614 \\ ${ }^{2}$ Azerbaijan University of Architecture and Construction, Baku, Azerbaijan, agayev.asef@mail.ru, \\ +994503620531
}

\begin{abstract}
The paper analyses the economic potentials of renewable energy resources in Azerbaijan and current economic challenges, as well as circumstances, emerged in the country's energy sector. Azerbaijan reserves great potential for renewable energy including efficient wind and solar resources, biomass, geothermal, and hydropower. Although there is no significant investment in the renewable energy sector in Azerbaijan, the government is currently working to stimulate investment in the inexhaustible energy sector. A higher share of renewable energy resources in the energy combination could bring the country many advantages including economic diversification in different fields. This sector can be a catalyst for new employment opportunities in the country that has traditionally been dominated by oil and gas and can lead to technological innovation, the opening up of new sectors, and economic growth to create economic value. Besides, the rapid deployment of renewable energy, combined with the continuous improvement of energy efficiency, can reduce domestic consumption of oil and gas, which will be allowing for additional revenues through exports and reduced domestic subsidies in the country.
\end{abstract}

\section{Keywords}

Renewable energy; economic challenges; energy economy; diversification; Azerbaijan.

\section{JEL Classification}

F41, F63, P18, P48

DOI: https://doi.org/10.14311/bit.2020.03.06

Editorial information: journal Business \& IT, ISSN 2570-7434, CreativeCommons license (c) (i) published by CTU in Prague, 2020, http://bit.fsv.cvut.cz/ 


\section{Introduction}

In a globalizing world, as the world's population grows, so does the demand for energy resources is significantly increasing. According to the International Energy Agency report, the global energy demand will go up by $50 \%$ in 2030 . Like other energy-rich countries, Azerbaijan also continues to take clear-cut measures and steps to improve the efficiency of resource use as a result of the growing demand for energy resources. The country has the potential to use both alternative and traditional (oil and gas) energy resources to meet with its domestic energy demand. However, at present, there is an urgent need to build up energy infrastructures based on high standards for the proper development and usage of alternative energy resources in the country. Despite being in the top 20th rank among countries with having proven reserves of crude oil and ranked in 25th place for natural gas, Azerbaijan is still working to undertake appropriate measures to develop the alternative energy sector. In this regard, Azerbaijan's energy-based activities are aimed at not only reducing dependence on conventional energy resources but also providing the diversification and efficient use of both energy resources in the future.

On 9 April 2019, the German-Azerbaijani Chamber of Commerce (AHK Azerbaijan) together with the German Trade and Investment Company (GTAI) published "Market Analysis Azerbaijan 2019" report, describing the work done by the country to modernize the conventional energy production and distribution sectors. The report also examines 15 important sectors of the Azerbaijani economy, including oil, gas, and other energy sources, and assesses non-traditional energy as a growing new area for foreign investment in the country.

According to the report of the German-Azerbaijani Chamber of Commerce on the assessment of energy potential in Azerbaijan, the total potential of wind energy in the country is more than 15,000 megawatts (MW). Wind blowing in Azerbaijan constitutes more than 250 days a year and can produce more than 2.4 billion kilowatt-hours $(\mathrm{KW} / \mathrm{h})$ of electricity per year. It should be noted that the current demand for green or non-traditional energy resources in the country is not limited to wind energy. After the wind, another alternative energy source in demand in the country is solar energy, which is present in any part of Azerbaijan between 2400 and 3200 hours. (German-Azerbaijan Chamber of Commerce, 2019)

It is known that the development of Azerbaijan's oil and gas sector over the past two decades has turned the country into a reliable energy exporter, and the growing demand has recently created the potential for investment and development in the non-oil sector. To develop the country's renewable energy potential, Azerbaijan is stepping up its efforts to attract private and foreign investments in the alternative energy sector by closely cooperating with international energy companies and financial institutions.

Arseniy Mitko, the Vice-president of the Arctic Academy of Sciences, PhD in technical sciences, associate professor of St. Petersburg State Aerospace Instruments University in Russia, points out that Azerbaijan's long-term goal by 2030 is to achieve a 30 percent (\%) share of renewable energy in the energy balance and to get a 30 percent (\%) reduction in greenhouse gas emissions compared to the 1990s. Azerbaijan's national energy system has significant energy saving potential in the transport sector. CIS countries, including Azerbaijan, have great potential in the field of renewable energy sources according to world standards. However, in this regard, the construction of appropriate infrastructure and transparent application of unified energy legislation on alternative energy sources is inevitable. Mitko also stressed that the EU provides financial assistance to Azerbaijan to achieve its goals. (Azernews, 2020)

In September 2018, the International Renewable Energy Agency (IRENA) submitted a draft report to the Ministry of Energy of the Republic of Azerbaijan on the "Azerbaijan Renewable Readiness Assessment". The report ("RRA - Renewable Readiness Assessment") provides information on potential improvements in Azerbaijan's legal and regulatory framework, as well as methods of financing 
renewable energy sources. Despite Azerbaijan's reliance on existing oil and gas resources, the country has significant prospects for the development of existing efficient wind and solar resources, biomass, geothermal, and hydropower. The Ministry of Energy of the Republic of Azerbaijan, in collaboration with the International Renewable Energy Agency (IRENA), conducted this study to lay the groundwork for renewable energy investment. (IRENA - International Renewable Energy Agency, 2019)

Table 1 mentioned below depicts the report of the International Renewable Energy Agency on Assessment of Readiness for the use of renewable energy sources in Azerbaijan, which embodies important proposals for the proper and effective implementation of the renewable energy policy of the Azerbaijani side.

Table 1 Important proposals by IRENA for the implementation of the renewable energy policy of Azerbaijan

- Development and adoption of a single draft law on renewable energy resources.

- $\quad$ Simplification of permitting procedures for renewable energy

- Improving the procurement process for renewable energy

- Establishment of special financing mechanisms to eliminate trade risk

- Implement a standard energy purchase agreement format

- $\quad$ Long-term development scenarios for variable renewable energy sources (ie solar and wind)

- Development and implementation of a network connection code with solar and wind integration standards

- $\quad$ Set up a capacity-building strategy and increase awareness in this area

- Adoption of long-term goals in the field of renewable energy sources

Source: Renewables Readiness Assessment: Republic of Azerbaijan Report by the International Renewable Energy Agency. (IRENA)

In general, renewable energy sources can play a pivotal role in supporting Azerbaijan's efforts to diversify its economy concerning different sectors and in increasing its gross domestic product. In this regard, Azerbaijan's review for the period after 2025 envisages the establishment of a strong competitive economy based on the development of high technologies and the optimal structure of the economy, providing a high level of social security and human development.

\section{Key statistical indicators of renewable energy resources and the attraction of foreign investment}

As a major producer of crude oil and natural gas, Azerbaijan has one of the highest energy selfsufficiency ratios in the world. Although there is no significant investment policy in the renewable energy sector in Azerbaijan, the government is currently working to accelerate private and foreign investments in this field. Besides, the government continues to work on a new energy strategy that will lead to another positive policy change called "Strategic Roadmap for the Development of the Municipal Sector of Azerbaijan", which is considered necessary in terms of implementing several important measures outlined in Table 2. 
Table 2 Some measures considered important to be implemented in the Strategic Road Map

- Increasing the National Generation Portfolio

- Diversification of National Generation Portfolio

- Consider increasing electricity exports to neighboring countries

- Increase the efficiency of power plants and efficient use of available capacity

- Reduce energy loss and improve the quality of transmission and distribution of electricity

- Use of optimal mechanisms to increase energy efficiency

- Reduction of all types of losses associated with the distribution of natural gas

- Expansion of the optimal heating system in the country

Source: Strategic Roadmap for the Development of the Municipal Sector of Azerbaijan

The reforms in the energy sector, which are included in the abovementioned Strategic roadmap, envisage the creation of a stable energy market in the country based on the experience of European countries, as it can increase the efficiency, level, and quality of services. Currently, all available energy sources - oil and other petroleum products, natural gas, and energy from large rivers (hydropower plants - HPPs) in Azerbaijan are considered the most developed sector compared to the rest of the inexhaustible energy assets. The country is thrilled to continue to develop energy sources such as wind, solar, and the share of alternative energy resources in the overall balance of energy consumption, which is expected to increase sharply in the next decade in Azerbaijan.

The use of renewable energy sources in Azerbaijan could have a positive impact on increasing the level of electricity supply, reducing the overall cost of electricity generation, saving natural resources, creating new jobs and protecting the environment. However, except for large hydropower plants (HPPs) in the country, the use of renewable energy reserves is generally small compared to their capacity. Therefore, to diversify electricity generation in Azerbaijan, it is planned to make extensive use of alternative energy sources, especially the great potential of wind and solar energy. Table 3 below shows the supply of renewable energy resources in Azerbaijan between 2015 and 2018.

Table 3 Renewable energy supplies in Azerbaijan for 2015-2018

\begin{tabular}{|c|c|c|c|c|}
\hline \multirow{2}{*}{ Energy reserves in total } & 2015 & 2016 & 2017 & 2018 \\
\hline & 15569,40 & 15393,50 & 15471,90 & 15556,10 \\
\hline Hydro energy & 140,8 & 168,5 & 150,2 & 152 \\
\hline $\begin{array}{l}\text { The share of hydropower in total energy consumption, in } \\
\text { percent (\%) }\end{array}$ & 0,9 & 1,1 & 1 & 1 \\
\hline Biomass and wastes & 160,7 & 100,8 & 102,4 & 110,7 \\
\hline $\begin{array}{l}\text { The share of biomass and waste in total energy } \\
\text { consumption, in percent (\%) }\end{array}$ & 1 & 0,7 & 0,7 & 0,7 \\
\hline Wind energy & 0,4 & 2 & 1,9 & 7,1 \\
\hline $\begin{array}{l}\text { The share of wind energy in total energy consumption, in } \\
\text { percent }\end{array}$ & 0 & 0 & 0 & 0,1 \\
\hline Solar energy & 0,4 & 3 & 3,2 & 3,4 \\
\hline $\begin{array}{l}\text { Share of solar energy (photoelectric) in total energy } \\
\text { consumption, in percent (\%) }\end{array}$ & 0 & 0 & 0 & 0 \\
\hline Total renewable energy supply & 302,3 & 274,3 & 257,7 & 273,2 \\
\hline $\begin{array}{l}\text { Share of total renewable energy supply in total energy } \\
\text { consumption, in percent (\%) }\end{array}$ & 1,9 & 1,8 & 1,7 & 1,8 \\
\hline
\end{tabular}

Source: State Statistics Committee of the Republic of Azerbaijan, 2019 
Electricity production in Azerbaijan is mainly carried out from two types of sources, and 94\% of which is generated from natural gas, the remaining $6 \%$ of it from hydropower and other power plants. The use of lower-cost energy resources including renewable ones could reduce the average cost of electricity generation. President Ilham Aliyev mentioned at the "Energy Security" roundtable in Munich, Germany, in 2020 that the government is planning to provide 30 percent of electricity by 2030 with its renewable energy. "This year, Azerbaijan has signed two contracts with leading companies specializing in alternative energy for the construction of $440 \mathrm{MW}$ wind and solar power plants. This work will be carried out entirely at the expense of foreign investment and we do have at least five proposals in this regard "the state leader highlighted in his speech during the official meeting. (APA, 2019)

Solar panels are one of the most affordable sources in the world and are especially promising for sunny areas. Solar energy with a total capacity of $8,000 \mathrm{MW}$ is the second largest one in Azerbaijan. The country's natural climate provides ample opportunities to increase the production of electricity and heat using solar energy. Since the number of sunny hours in Azerbaijan during the year is 2400 to 3200 hours, showing that the amount of sunlight falling on the territory of Azerbaijan is higher than in other countries. At the same time, it can be considered as one of the efficiency criteria for attracting investment in the use of solar energy. It should be noted that the development of this energy can partially solve energy problems in several regions of Azerbaijan.(Caspian news, 2019)

Due to its geographical location, Azerbaijan is one of the countries where windmills can be effectively adapted. In particular, the Absheron Peninsula, the Caspian Sea coast, and the islands in the northwestern part of the Caspian Sea, the Ganja-Dashkesan zone in western Azerbaijan and the SharurJulfa area of the Nakhchivan Autonomous Republic are suitable areas for the use of windmills. In 1999, the Japanese company Tomen, together with the Azerbaijan Scientific Research Energy Institute, installed two towers 30 and 40 meters long in Absheron. It was determined that the average annual wind speed was 7.9-8.1 m/s and the feasibility study was prepared for the installation of windmills with a total capacity of $30 \mathrm{MW}$ in the Gobustan region.

According to the Market Analysis Azerbaijan 2019 report published by the German-Azerbaijani Chamber of Commerce, the potential of wind energy constitutes 59.2 percent of total renewable sources in the country. Here, the wind blows for more than 250 out of 365 days and has the potential to generate 2.4 billion kilowatt-hours ( $\mathrm{kWh}$ ) of electricity per year. (German-Azerbaijan Chamber of Commerce, 2019) The first descriptions in the renewable energy sector are based on the development of large-scale wind energy projects. Thus, the "Azalternativenerji" company is currently evaluating a wind energy project at the Baku International Sea Trade Port, which is the first offshore wind farm in the Caspian Sea called the "Wind Island-1" project. Another wind power plant will have a capacity of $200 \mathrm{MW}$ and will be installed in the area between Pirallahi settlement and Chilov Island. (Gregory B. Poindexter, 2018)

From an environmental point of view, water is considered the cleanest renewable energy source in the world. Electricity production from this source has been increasing in Azerbaijan since 1990. The share of hydropower production capacity is currently $17.8 \%$ of total energy. The country also has ample opportunities to develop unused hydropower resources. As a result of the construction of hydropower plants in the country, floodwaters are regulated, electricity is generated and new irrigation systems are created. The rivers in the country are suitable for small hydropower plants. At the same time, Azerbaijan has completed major modernization and restoration work at the $425 \mathrm{MW}$ Mingachevir station. With the bilateral support of Iran, the country announced significant progress in early 2019 on two new hydropower plants called "Khudaferin" and "Maiden Tower" on the Araz River. (Renewables 2019, 2019) 
Biomass and wastes are also important as alternative energy sources, which have several sources of them in Azerbaijan: industrial wastes, forest, and wood processing wastes, agricultural and organic, household and communal wastes, and wastes from areas contaminated with oil and its products. According to the research, most of the waste consists of biomass products and waste in all sectors of the economy. These biomass substances can be obtained from gas, liquid, and solid biomass used in the production of electricity. More than 2.0 million tons of solid and industrial wastes are dumped in landfills in Azerbaijan every year. Their processing can partially solve the problem of heating public buildings in Baku and other industrial cities of the country. (UNECE, 2019)

Thus, biomass, geothermal, and hydropower plants are presented as the next promising renewable energy sources with a capacity of $900 \mathrm{MW}, 800 \mathrm{MW}$, and $650 \mathrm{MW}$, respectively. Table 4 described below provides information on the expansion of renewable electricity production in Azerbaijan by 2030.

Table 4 Renewable electricity production in Azerbaijan by 2030

\begin{tabular}{|l|c|c|c|}
\hline \multicolumn{1}{|c|}{ Divisions } & $\mathbf{2 0 1 8 - 2 0 2 0}^{*}$ & $\mathbf{2 0 2 1 - 2 0 2 5}$ & $\mathbf{2 0 2 6 - 2 0 3 0}$ \\
\hline All divisions & 430 & 840 & 925 \\
\hline Wind energy & 350 & 440 & 465 \\
\hline Solar energy & 50 & 150 & 190 \\
\hline Hydro energy & 10 & 220 & 220 \\
\hline Biomass and wastes & 20 & 30 & 50 \\
\hline
\end{tabular}

Source: State Statistical Committee of the Republic of Azerbaijan, composed by the author.

Due to the lack of attention paid to the alternative energy sector in Azerbaijan in the 2000s, the sustainable development in this field was slow compared to oil and gas production. However, the current government has made the energy sector a priority, with a target of $20 \%$ renewable energy in electricity generation by 2020 . (According to statistics by the government this figure was up to $12 \%$ in 2012.) The government agency in charge of alternative energy resources is currently working on a new strategy and on a single bill that is expected to accelerate its use and attract foreign investment. At the same time, the government is seeking to increase private and foreign investment in the renewable energy field through supportive policies and incentives. Table 5 shows the new production capacity of the energy system in Azerbaijan for 2019-2030. 
Table 5 The new production capacity of the energy system in Azerbaijan for 2019-2030

\begin{tabular}{|c|c|c|c|c|c|c|c|c|c|c|c|c|c|c|}
\hline № & Power Plants & Unit & 2019 & 2020 & 2021 & 2022 & 2023 & 2024 & 2025 & 2026 & 2027 & 2028 & 2029 & 2030 \\
\hline I & $\begin{array}{l}\text { New capacity- } \\
\text { total: }\end{array}$ & MW & 785 & 785 & 1007 & 1089 & 1171 & 1713 & 1795 & 2567 & 2879 & 2891 & 2903 & 3515 \\
\hline 1 & Shimal PP (CCP-2) & MW & 400 & 400 & 400 & 400 & 400 & 400 & 400 & 400 & 400 & 400 & 400 & 400 \\
\hline 2 & Ag Sheher TPP & MW & & & & & & & & 300 & 300 & 300 & 300 & 300 \\
\hline 3 & Sheki PP & MW & & & & & & & & & & & & 200 \\
\hline 4 & Astara (Masalli) PP-2 & MW & & & & & & & & & & & & 200 \\
\hline 5 & HacmazPP-2 & MW & & & & & & & & & & & & 200 \\
\hline 6 & Shirvan 2 TPP & MW & & & & & & & & & 300 & 300 & 300 & 300 \\
\hline 7 & SangacalPP 2 & MW & 385 & 385 & 385 & 385 & 385 & 385 & 385 & 385 & 385 & 385 & 385 & 385 \\
\hline 8 & Yashma PP & MW & & & & & & 460 & 460 & 920 & 920 & 920 & 920 & 920 \\
\hline \multicolumn{2}{|c|}{ TOTALPP } & MW & 785 & 785 & 785 & 785 & 785 & 1245 & 1245 & 2005 & 2305 & 2305 & 2305 & 2905 \\
\hline 9 & HudaferinHPP & MW & & & 100 & 100 & 100 & 100 & 100 & 100 & 100 & 100 & 100 & 100 \\
\hline 10 & Gizgalasi HPP & MW & & & 40 & 40 & 40 & 40 & 40 & 40 & 40 & 40 & 40 & 40 \\
\hline 11 & Small HPPs & MW & & & 12 & 24 & 36 & 48 & 60 & 72 & 84 & 96 & 108 & 120 \\
\hline \multicolumn{2}{|c|}{ TOTAL HPP } & MW & & & 152 & 164 & 176 & 188 & 200 & 212 & 224 & 236 & 248 & 260 \\
\hline 12 & APP (wind, solar) & MW & & & 70 & 140 & 210 & 280 & 350 & 350 & 350 & 350 & 350 & 350 \\
\hline
\end{tabular}

Source: State Statistical Committee of the Republic of Azerbaijan

Despite widespread privatization since independence, Azerbaijan's energy sector is largely stateowned. Only the small part hydropower plants are privately owned and account for less than $1 \%$ of electricity generation. (EU4energy, 2019) According to Alasgar Hasanov, Director of the Department of Energy Efficiency and Ecology of the Ministry of Energy of Azerbaijan, the potential capacity of renewable energy sources in Azerbaijan is 26,940 megawatts, including 3,000 megawatts of wind energy, 23,040 megawatts of solar energy, 380 megawatts of bioenergy and 520 megawatts is calculated as a mountain river hydroelectric power station. Hasanov also said that in terms of renewable energy sources in Azerbaijan, the total production capacity of power plants constitutes 7,556 megawatts, including the capacity of major hydropower plants, is 1,276 megawatts, which is $17 \%$ of the total capacity.

The main goal is to create a favorable investment climate in the country to attract businesses to the development of the renewable energy industry," - he added. To this end, the first steps are being taken to improve the legal framework in this field. Azerbaijan has drafted a law on the use of renewable energy sources in electricity generation and is currently considering it. At the same time, close cooperation continues to be established with foreign companies, and negotiations have begun on the implementation of renewable energy projects in Azerbaijan (Azernews, 2020)

On January 9, 2020, the Cabinet of Ministers of Azerbaijan, the Ministry of Energy, and ACWA Power of Saudi Arabia and Masdar of the UAE signed executive agreements for the implementation of pilot projects on the construction of wind and solar power plants. The contract with ACWA Power includes the construction of a 240-megawatt wind farm and a 200-megawatt solar power plant. The company currently has a product portfolio of 30,200 megawatts with a total renewable energy capacity of 8,000 megawatts and an investment portfolio of $\$ 45$ billion. As for Masdar, it currently has a product portfolio in the field of renewable energy with a total installed capacity of 4,000 megawatts and has so far invested $\$ 8.5$ billion in this area. (Caspianpower, 2020)

At the same time, the foreign investors from China, Canada, Turkey, the United States, and Norway, as well as Arab and the EU member states have expressed interest in entering the alternative energy 
market in Azerbaijan, focusing mainly on wind energy projects. Given the declining foreign exchange earnings from oil exports in the country bordering the Caspian Sea and the lack of green energy experience in the domestic market, there is an urgent need to attract foreign investment and technology in the alternative energy sphere. (German-Azerbaijan Chamber of Commerce, 2019)

The operation of the "New Yashma Wind Energy Park" is very important in terms of the alternative energy market. The creation of such parks will be serving to ensure sustainable energy supply in Azerbaijan, increasing export revenues, and improving the environmental situation in the country. In 2019, the park produced about 90 million kWh of electricity, which will save 30 million $\mathrm{m} 3$ of natural gas per year. (Azernews 2019) Simultaneously, the development of the agricultural industry in Azerbaijan opens wide opportunities for the production of biomass energy. "In this regard, cooperation between SOCAR and SNAM in the field of renewable gas development and sustainable energy use is important for the development of biogas and biomethane production. Besides, the development of biomethane and hydrogen could offer new opportunities for the supply of renewable gases through the Southern Gas Corridor and the TAP pipeline, by enhancing environmental sustainability along with security and supply elasticity. (SOCAR, 2020) The investment in green energy in Azerbaijan in 20182020 is shown in Table 6 below.

Table 6 Investment in green energy for 2018-2020*

\begin{tabular}{|l|c|c|c|}
\hline Division/project & $\begin{array}{c}\text { Operation capacity } \\
\text { (MW) }\end{array}$ & $\begin{array}{c}\text { Project } \\
\text { (in number) }\end{array}$ & $\begin{array}{c}\text { Project value } \\
\text { Million USD }\end{array}$ \\
\hline General projects & 420 & 23 & 678.4 \\
\hline Wind energy & 350 & 6 & 555.4 \\
\hline Solar energy & 50 & 10 & 63 \\
\hline Bioenergy & 20 & 7 & 60 \\
\hline
\end{tabular}

* except for hydropower projects

Source: Utility Development Strategy of the Government of Azerbaijan (December 2016)/State Statistical Committee of Azerbaijan Republic/composed by the author

According to the Strategic Road Map approved by the Presidential Decree dated December 6, 2016, to achieve national economic progress, the following are the main target indicators:

- Increasing the share of direct investment in the non-oil sector by 2025 from the current $1.5 \%$ to $4 \%$;

- Increase non-oil sector exports per capita from the current level of $\$ 200$ to $\$ 450$ by 2025 and to $\$ 1,200$ by 2035 .

Finally, it should be noted that like other countries, Azerbaijan is highly dependent on oil and natural gas consumption. Even in some countries, the share of natural gas in total gas consumption is 85 percent, who are interested in reducing their dependence on oil and natural gas by using alternative energy sources in the medium and long term. Thus, by producing solar and wind power plants, Azerbaijan can make alternative energy production more efficient domestically and increase export revenues by selling it to foreign countries. 


\section{The main problems and limitations of renewable energy resources}

The research confirmed that despite the growing interest in renewable energy, Azerbaijan still encounters some challenges in the efficient use of its inexhaustible resources. In this regard, the government faces four main challenges involving 1. financial, 2. technical, 3. institutional/regulatory, and 4. information barriers. The first is the legal problems for both the production and use of renewable energy sources. Currently, appropriate measures are being taken by the government to establish a legal framework for this sector. Moreover, the investment in renewable energy in the country must be carried out on a sustainable basis, mainly by the government and international organizations, and in this regard, the bill is still under discussion. On the other hand, the significant technical, legal, and regulatory infrastructures are not considered satisfactory for building an efficient business environment in the renewable energy sector. In this regard, the current conditions make it difficult for private entities to invest and therefore, do not ensure efficiency.

The second is due to the technical difficulties that the country faces in transferring technology, as the technologies used for the use of renewable energy sources are expensive investments. Given that Azerbaijan imports them from other countries, technical procedures need to be simplified. Azerbaijan's electricity has long dominated the oil and natural gas and is more experienced in traditional methods than the renewable ones. The lack of financial resources and high-interest rates are the third obstacle, creating difficulties in the country. Thus, the fall in oil prices since mid-2014 has had a serious impact on the Azerbaijani economy. The fourth major problem encompasses the lack of awareness in the renewable energy sphere, as no support from international organizations and local authorities to raise public awareness about renewable energy sources in Azerbaijan.

Azerbaijan aims to achieve economic growth in line with the UN Sustainable Development Goals and plans to generate $20 \%$ of its electricity from renewable sources by the end of 2020. Enhancing Azerbaijan's renewable energy sector would help it meet its commitments to reduce greenhouse gas emissions under the 2016 Paris Agreement on Climate Change. (Eurasia net, 2020) If the country plans to achieve the UN Sustainable Development Goals and the Paris Agreement, it should have to expand funding for environment-friendly investments such as new financial instruments and policies, such as green bonds, green banks, carbon market instruments, and fiscal policy. On the other hand, the government should try to implement green central banking, a fintech program (a technology used to support or use banking and financial services), community-based green funds, and other measures commonly known as "green finance." (Sachs, J., W. T. Woo, N. Yoshino, and F. Taghizadeh. H. 2019)

Currently, the government has developed an Action Plan for the effective exploitation and investment of renewable energy supplies. These planned steps not only could increase the interest in using those resources but also encourage the country to improve the technology used in this area. Examples of this are the Azguntex Solar Panel Plant with an annual estimated production capacity of 50 megawatts and the Solar Collector Plant in Sumgayit Technology Park. Despite all these steps, expensive investments in this sphere are mainly still made by the government compared to foreign or private investors, and in this regard, Azerbaijan's renewable energy capacity and share in total renewable electricity production are lower than expected. (Yoshino, N., F. Taghizadeh-Hesary, and M. Nakahigashi, 2019) Thus, the lack of development of the renewable energy sector in the country relates mainly to the weak involvement of the private/foreign sectors in long-term investments. The main reason for not being interested in long-term financing of infrastructure projects including green energy projects by those companies is the low rate of returns and associated risks. Therefore, the country's pivotal goal is to develop the alternative energy sector by attracting investments to the private sectors and creating a legal framework that could stimulate them. The negotiations are underway with companies, international organizations and financial institutions interested in investing in the non-traditional energy sector in 
Azerbaijan to discuss proposals for the draft laws, as those will determine the future development of this sector in the country.

\section{Conclusion}

Finally, it should be noted that the geographical location of Azerbaijan creates favorable conditions for the development of the renewable energy field. In recent years, falling oil prices have limited public investments and activities in this area. The situation has also released out that this sector cannot be developed merely with state capital and its active participation, and which should also be grown with the active involvement of private/foreign investments. Hence, the government should have to create an attractive environment for investors in competitive market opportunities. The latest alternative technical potential in Azerbaijan is estimated at 130,000 megawatts (MW) per year. To achieve the goal of efficient use of $20 \%$ renewable energy resources by 2020 , legal, financial and technical difficulties must be quickly eliminated and public awareness of the non-traditional sector must be increased. Until recently, there has been no in-depth analysis of the economic potential of Azerbaijan's renewable energy resources and sustainable use of them.

Ensuring well-supplied infrastructures for alternative energy reserves, the effective organization of energy economy, and transparent energy administration are key factors that can play a crucial role in ensuring energy security in the country. Azerbaijan has considerable potential for the production and use of both traditional and alternative energy resources, but oil and gas production still accounts for a large share of energy production. It would be more accurate to call the Azerbaijani economy dependent on oil and gas. Although the sustainable use of Azerbaijan's alternative energy resources is possible in the coming future, it is immensely necessary to attract foreign trade to Azerbaijan's renewable energy sphere by making appropriate strategic decisions and measures on it.

\section{References}

[1] APA (2020) President Ilham Aliyev attended Energy Security round table as part of Munich Security Conference, Available at: https://apa.az/en/foreign-news/President-Ilham-Aliyev-attended-Energy-Securityround-table-as-part-of-Munich-Security-Conference-colorredUPDATEDcolor-312830

[2] Azernews (2020). Azerbaijan working to attract investments into its renewable energy industry, Available: https://www.azernews.az/oil and gas/162480.html

[3] Azernews (2020). Expert hails Azerbaijan's alternative energy potential, Available at: https://www.azernews.az/oil and gas/162206.html

[4] Caspiannews (2019) Renewable Power in Azerbaijan Gears Up with Arabic Investments, Mövcuddur: https://caspiannews.com/news-detail/renewable-power-in-azerbaijan-gears-up-with-arabic-investments2020-2-19-30/

[5] Caspianpower, (2020). Azerbaijan working to attract investments into its renewable energy industry, Available: https://caspianpower.az/en-opennews/8316.41.html

[6] Eurasia net (2020). Azerbaijan looks to renewables to meet growing power demand, Available at: https://eurasianet.org/azerbaijan-looks-to-renewables-to-meet-growing-power-demand

[7] German-Azerbaijan Chamber of Commerce (2019). Market Analysis Azerbaijan 2019, Available at: https://www.aserbaidschan.ahk.de/fileadmin/AHK Aserbaidschan/Publikationen/Marktanalyse Aserbaid schan 2019/Market Analysis Azerbaijan 2019.pdf

[8] Gregory B. Poindexter (2018). Modernization work completed at 424-MW Mingachevir hydro station in Azerbaijan, Available at: https://www.hydroworld.com/articles/2018/02/modernization-work-comple

[9] International Energy Agency for EU4Energy (2019) Azerbaijan-Country Overview, Available at: https://www.eu4energy.iea.org/Pages/CreatePDF.aspx?Country=Azerbaijan

[10] IRENA (2019). Renewables Readiness Assessment: Republic of Azerbaijan Report, Available at: file://C:/Users/Admin/Downloads/IRENA RRA Azerbaijan 2019.PDF

[11] Renewables 2019, (2019) Global Status Report, Renewable Energy Policy Network for the 21 $1^{\text {st }}$ Century, Available: https://www.ren21.net/wp-content/uploads/2019/05/gsr 2019 full report en.pdf 
[12] Sachs, J., W. T. Woo, N. Yoshino, and F. Taghizadeh. H (2019). Importance of Green Finance for Achieving Sustainable Development Goals and Energy Security, In Handbook of Green Finance: Energy Security and Sustainable Development

[13] SOCAR (2020). SNAM AND SOCAR sign and agreement to promote sustainable energy, Available: http://www.socar.az/socar/en/news-and-media/news-archives/news-archives/id/11440

[14] UNECE (2019). National Sustainable Energy Action Plan of Azerbaijan, Available at: https://www.unece.org/fileadmin/DAM/projectmonitoring/unda/16 17X/E2 A2.3/Action_Plan_of_Azerbaijan-new-03.12.2019.pdf

[15] Yoshino, N., F. Taghizadeh. H, and M. Nakahigashi (2019). Modelling the Social Funding and Spillover Tax for Addressing the Green Energy Financing Gap. Economic Modelling 77. pp. 34-41 